\title{
The publication of case studies and confidentiality - an ethical predicament
}

\author{
Anne Patterson
} Writing about psychoanalysis or psychotherapy
has traditionally included illustrative clinical
material which helps to clarify and enliven
complex theories. However, there is increasing
interest in the ethical questions raised by the
publication of confidential clinical material,
informed by a post-modern culture emphasising
individual rights and empowerment, increasingly
supported in law, and equally, fascinated by
celebrity and disclosure. It seems important for
psychiatrists to engage in this debate which has
implications for the future communication of
clinical findings between psychotherapists and
psychiatrists.

The Hippocratic Oath declares that the doctor has a cardinal duty to protect the right of the patient to confidentiality. This ancient and fundamental principle is reflected in contemporary medical guidelines (Royal College of Psychiatrists, 1989; General Medical Council, 1995). To publish clinical material presents a conflict of interest between doctor and patient. However, strict adherence to ethical principles is rare. The Corpus Hippokraticum, allegedly written by Hippocrates, describes the illness of Cleanactides such that he would be clearly identifiable by his contemporaries (Fichtner, 1997). More recently this dilemma has received the attention of writers on psychiatric ethics, such as Joseph \& Onek (1991) who stress the importance of 'meaningful consent' such that a psychiatrist who wants to publish clinical material must show the patient what has been written and secure the patient's agreement to proceed with publication. The current advice to contributors to the British Journal of Psychiatry was defined in an editorial by Wilkinson et al (1995) who sought both medical and legal opinions on the guidelines. There was concern from doctors that an obligation to obtain consent would deter authors from publishing case reports with a consequent impoverishment of the literature, but, like the ethicists, legal opinion confirmed the need for written consent without which the material could only be presented so that there was no disclosure and the patients concerned could not recognise themselves. Attempts to justify publication without consent in terms of the benefits to science or to future patients, that is, a defence in the public interest, would not be upheld in court as there are many ways of conducting psychiatric research which do not threaten the confidentiality of the patient.

There is a growing body of empirical research in psychotherapy particularly concerning the evaluation of clinical effectiveness. Nevertheless, the advancement of new theories is largely dependent on the presentation of clinical data to demonstrate the author's ideas (Klumpner \& Frank, 1991; Wyman \& Rittenberg, 1992). Indeed, Rustin (1997) compares the psychoanalytic consulting room with the laboratory. The 'Notes for Contributors' in the International Journal of Psycho-Analysis (1998) emphasises both the need for confidentiality and the importance of including supporting clinical materal. The dilemma is stated succinctly by Bollas \& Sundelson (1995):

"losing the ability to write up clinical cases would be a mortal blow to the intellectual development of psychoanalysis. If, as we argue, confidence must be maintained under all circumstances how can writing about a patient ever be warranted?"

Securing consent for publication is presented as a solution but actually generates further complex questions. A need that is unrelated to the patient is brought into the consulting room (Furlong, 1998) and many analysts are therefore uneasy about asking (Lipton, 1992). The response is inevitably coloured by the vicissitudes of the transference relationship, thus compromising the possibility of informed or meaningful consent (Stoller, 1988; Goldberg, 1997). Reading the article is likely to affect the patient's view of the treatment in unpredictable ways. In treatment there is careful thought about how an intervention will be received by the patient, but in writing for publication a different audience is being addressed. The patient may not be helped by reading a detailed description of the analyst's feelings during the treatment although this may 
be important to present to professional colleagues. There may even be disputes over the accuracy of what has been written. Psychiatric ethicists think that material that might be harmful for patients to read should, despite the sacrifice, be left out of the publication (Joseph \& Onek, 1991). Such omissions inevitably distort the arguments presented and gaps might appear in the literature. Paradoxically, it might become almost impossible to write about the most difficult clinical problems where discussion and new ideas are most vital; for example, failed treatments, psychopathy, perversion and pathological narcissism.

Whether or not consent has been secured for the publication of clinical material attempts are made to safeguard confidentiality usually by disguising the patient, delaying submission until after the treatment is finished and publishing in a professional journal which is not thought to be widely read by the public. These strategies are often presented as further solutions to the ethical problems under discussion but also pose uncomfortable questions. When permission has not been obtained these measures supposedly introduced for the protection of the patient also serve to conceal the author's breach of confidentiality. Even if all the personal details are changed the patient may still recognise the words and feel betrayed (Stoller, 1988) and in all cases disguise will threaten the validity of the report (Spence, 1998). Words spoken by a male teacher have different significance if attributed to a female nurse and transform the meaning of the original material. Delay of publication assumes that the transference is completely dissolved at the end of treatment which is surely questionable and publication for a restricted readership ignores the widespread access to information in contemporary society. The precautions were suggested by Freud when he wrote about Dora without her consent (Freud, 1905). However, Dora may have presented particular problems with regard to permission because she had abruptly ended the analysis herself and Freud went on to consider the dilemma further, gaining consent to write about his remaining major cases and acknowledging that he had to exclude material in the interests of confidentiality (Freud, 1909).

In conclusion, there does not seem to be a comfortable way to resolve this ethical dilemma. There is a duty to protect the confidentiality of the individual patient, enshrined in medical ethics since ancient times. There is also a need for the continuing publication of clinical material, which remains important in the advancement of psychoanalytic knowledge which will benefit patients. Goldberg (1997) warns against resorting to complacent certainty and suggests that it is important to acknowledge that there are difficulties in the way in which clinical material is presented for publication. Ethical guidelines, although imperfect, already exist and their application and refinement need careful consideration and continuing debate. However, this requires an unpleasant struggle, not only for those who write, but also for those who read about clinical material, in remaining aware of the inherent ethical contradictions. Personally, I would prefer, with misgivings, to ask for consent, recognising the intrusion and hoping that, like other intrusions into the consulting room, such as a meeting between patient and analyst in the supermarket or at a conference, the matter could be openly addressed with the patient. Perhaps in sustaining a discussion about the publication of clinical material there is a challenge, and much hard work, in remaining uncomfortable.

\section{Acknowledgements}

I would like to thank Dr J. Atkinson and Dr R. Whyte for their advice in the writing of this paper.

\section{References}

BOLLAS, C. \& SUNDELSON, D. (1995) The New Informants: The Betrayal of Confidentiality in Psychoanalysis and Psychotherapy. Northvale, NJ: Jason Aronson.

FichtNeR, G. (1997) Professional secrecy and the case history. Scandinavian Psychoanalytic Review, 20. 97106.

FREUD. S. (1905) Fragment of an analysis of a case of hysteria. In Standard Edition. Vol. 7 (ed. \& trans. J. Strachey). pp. 3-122. London: Hogarth Press.

- (1909) Notes upon a case of obsessional neurosis. In Standard Edition. Vol. 10 (ed. \& trans. J. Strachey). pp. 153-286. London: Hogarth Press.

FURLONG. A. (1998) Should we or shouldn't we? Some aspects of the confidentiality of clinical reporting and dossier access. International Joumal of PsychoAnalysis, 79, 727-740.

General Medical Counch (1995) Duties of a Doctor. London: GMC.

GOLDBERG. A. (1997) Writing case histories. International Joumal of Psycho-Analysis, 78, 435-438.

JOSEPH. D. \& ONEK. J. (1991) Confidentiality in psychiatry In Psychiatric Ethics. (2nd edn) (eds S. Bloch \& P Chodoff). pp.313-340. Oxford: Oxford Medical Publications.

INTERNATIONAL JOURNAL OF PSYCHO-ANALYSIS (1998) Notes for contributors. International Journal of Psycho-Analysis. 78, 211-214.

KLUMPNER, G. H. \& FRANK. A. (1991) On methods of reporting clinical material. Joumal of the American Psychoanalytic Association, 39, 537-551.

LiPTON, E. L. (1992) The analyst's use of clinical data and other issues of confidentiality. Joumal of the American Psychoanalytic Association, 39, 967-985.

Royal College of PSYCHIATRISTs (1989) Position Statement on Confidentiality. Councll Report CR7. London: Royal College of Psychiatrists. 
RUSTIN. M. (1997) What do we see in the nursery? Infant observation as laboratory work. Intemational Journal of Infant Observation, 1, 93-110.

STouler. R. J. (1988) Patients' responses to their own case reports. Journal of American Psychoanalytic Association, 38, 371-392.

SPENCE, D. P. (1998) Rain Forest or Mud Fleld? International Journal of Psycho-Analysis, 79, 643-647. Wilkinson, G.. FAHY, T. Russell, G., et al (1995) Case reports and confidentiality. Opinion is sought, medical and legal. British Journal of Psychiatry. 166. 555558.
WYMAN, H. M. \& RITtenberG, S. M. (1992) Reflections on the written presentation of psychoanalytic clinical data: Necessary source and perennial problem. Joumal of Clinical Psychoanalysis, 1, 323-331.

Anne Patterson, Senior Registrar in Psychotherapy. Carswell House, 5 Oakley Terrace, Glasgow G31 2HX

\section{Royal College of Psychiatrists}

A limited number of copies of the Department of Health's booklet

\section{Drug Misuse and Dependence Guidelines on Clinical Management}

(published April 1999) are available on application to the College.

Please send a cheque for $\mathbf{£ . 0 0}$ made payable to the Royal College of Psychiatrists and your full name and address to which the booklet should be sent, to:

Ms Nicola Pinn, Royal College Psychiatrists, 17 Belgrave Square, London, SW1X 8PG 